\title{
Impact of Anaemia on the Severity of Acute Bronchiolitis in Infants
}

\section{Elif Çelik ${ }^{1}$, Serkan Fazlı Çelik ${ }^{2}$, Şükrü Güngör ${ }^{3}$ and Adem Dursun ${ }^{4}$}

${ }^{1}$ Department of Paediatrics, General Paediatrics Unit, Adnan Menderes University, Faculty of Medicine, Aydin, Turkey

${ }^{2}$ Department of Paediatric Cardiology Unit, Adnan Menderes University, Faculty of Medicine, Aydin, Turkey

${ }^{3}$ Department of Paediatric Gastroenterology Unit, Adnan Menderes University, Faculty of Medicine, Aydin, Turkey

${ }^{4}$ Paediatric Intensive Care, Kayseri City Hospital, Kayseri, Turkey

\section{Correspondence: \\ Elif Çelik \\ Department of Paediatrics, \\ Adnan Menderes University, \\ Faculty of Medicine, \\ Aydın, Turkey \\ email: gencelif80@yahoo.com}

DOI: $10.3126 /$ jnps.v41i1.30704

Submitted on: $2020-08-19$

Accepted on: 2021-02-16

Acknowledgements: None

Funding: Nil

Conflict of Interest: None declared

Permission from IRB: Yes

To cite this article: Çelik E, Çelik SF, Güngör Ş, Dursun A. Impact of Anaemia on the Severity of Acute Bronchiolitis in Infants. J Nepal Paediatr Soc. 2021;41(1): 73-9.

\section{ABSTRACT}

Introduction: Although anaemia is a predisposing factor in the occurrence of lower respiratory tract infections, there is limited data about the relationship between anaemia and acute bronchiolitis in infants. The aim of this study is to determine whether anaemia is an independent clinical condition increasing the severity of acute bronchiolitis in infants.

Methods: This retrospective study was conducted on 163 infants (101 acute bronchiolitis and age and sex matched 62 controls), aged between one month to two years. According to the clinical severity of the disease, patients were divided as having mild, moderate and severe acute bronchiolitis. Haemoglobin $(\mathrm{Hb})$ level was considered low when below $11 \mathrm{gm} / \mathrm{dL}$, which is less than 2 standard deviation (SD).

Results: Median $\mathrm{Hb}$ and mean cell haemoglobin concentration (MCHC) levels were significantly lower in acute bronchiolitis patients than controls $\{10.1 \mathrm{gm} / \mathrm{dL}(9.6-10.6 \mathrm{gm} / \mathrm{dL}) \mathrm{vs} .11 .2 \mathrm{gm} / \mathrm{dL}$ $(10.6-12.1 \mathrm{gm} / \mathrm{dL}) ; \mathrm{p}<0.001)\}$, and $\{33.6(32.5-34.1 \mathrm{gm} / \mathrm{dL}) \mathrm{vs}$. $34 \mathrm{gm} / \mathrm{dL}(33.1-34.5 \mathrm{gm} / \mathrm{dL}) \mathrm{p}=0.012\}$. Conversely, median red cell distribution width (RDW) was higher $\{14.4 \%$ (13.5 - 15.6\%) vs. $14.1 \%(13.1-15 \%)\}$. When evaluated by logistic regression analysis, the risk of severe bronchiolitis increased 10 times in acute bronchiolitis patients with a $\mathrm{Hb}$ value $\leq 10 \mathrm{gm} / \mathrm{dL}$. Also, there was a significant negative correlation between $\mathrm{Hb}$ level and bronchiolitis severity $(\mathrm{r}:-0.423, \mathrm{p}<0.001)$. Furthermore, the patients who had $\mathrm{Hb}$ value under $9.95 \mathrm{gm} / \mathrm{dL}$ had risk of more severe bronchiolitis with $73.7 \%$ sensitivity and $83.3 \%$ specificity than other patients.

Conclusions: Anaemic infants are more susceptible to acute bronchiolits and as the degree of anaemia increases, they are more severely affected.

Keywords: acute bronchiolitis severity; haemoglobin level; infant

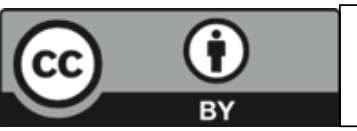

This work is licensed under creative common attribution 3.0 license 


\section{INTRODUCTION}

Acute bronchiolitis $(\mathrm{AB})$ is the most common acute lower respiratory tract infection (LRTI) in the first 24 months of life. Respiratory syncytial virus (RSV) is the main etiological agent. ${ }^{1}$ During the last few years, among US children hospitalisation rates have increased from $1 \%$ to $3 \%$ due to acute bronchiolitis which reflects significant morbidity. ${ }^{2-4,5}$ Several risk factors like gender, age, history of prematurity, underlying conditions like immunodeficiency or cardiopulmonary disease have been associated with the severity of bronchiolitis.

Iron deficiency anaemia (IDA) is a serious public health problem that impacts mental and physical development, health maintenance and work performance. Worldwide in over $40 \%$ of children, IDA has been associated with infections. ${ }^{6}$

Although anaemia is a predisposing factor in the occurrence of LRTI in children ${ }^{7-9}$ there is limited data about the effect of IDA on AB. In the present study, we aimed to evaluate whether lower $\mathrm{Hb}$ levels could be an independent risk factor for the clinical severity in infants with $\mathrm{AB}$.

\section{METHODS}

This retrospective study was conducted between September 2018 and May 2019 at the general paediatric ward of a tertiary medical centre in Turkey. Total 101 infants hospitalised with the diagnosis of the first $\mathrm{AB}$ attack and 62 healthy controls from one month to two years of age were included in the study. Ethics committee approval was obtained from the local Ethics Committee. Informed consent was not obtained from the participants caregivers due to retrospective design of the study.

The inclusion criteria for cases were children with symptoms of viral respiratory tract infection (cough, rhinorrhoea, nasal obstruction, tachypnea, retraction, prolonged expiration, and cyanosis), requiring supplemental oxygen, and ronchi or crepitations on auscultation. ${ }^{3}$ Patients were hospitalised in the presence of one or more than one symptoms including respiratory distress, poor feeding, dehydration, toxic appearance or lethargy, apnea, hypoxemia with or without hypercapnia. ${ }^{10}$ There was no specific golden criteria to differentiate bacterial (pneumonia) or viral (bronchiolitis). Diagnosis of bronchiolitis and pneumonia were coded according to the criteria suggested by Court as a prelude to a multi-centre study that was subsequently published. ${ }^{11,12}$

The severity of disease in all infants were assessed using a clinical scoring system that included general health status, respiration rate, heart rate and the presence of chest retractions. The children were categorised into mild, moderate and severe bronchiolitis groups according to Wang respiratory score. ${ }^{13}$ According to this; scores ranged from 1 to 3,4 to 8 and 9 to 12 in patients with mild, moderate, and severe $\mathrm{AB}$ respectively.

Infants who needed respiratory support (noninvasive or invasive mechanical ventilation) due to severe respiratory failure or apnea and who had a change in mental status at the time of admission were transferred to the paediatric intensive care unit (PICU). Physical examination and investigations like $\mathrm{CBC}$, peripheral blood smear and X-ray chest radiographs were done in all hospitalised cases on the first day of admission. Newborns or infants born prematurely, who had a known history of bronchopulmonary dysplasia, recurrent wheezing $(\geq 3$ ), chronic lung disease, congenital heart disease, non-respiratory infection, an immunodeficiency, history of any atopy, exposure to passive smoking and who transferred to PCIU were excluded from the study. Control group were recruited from the age and sex matched healthy infants who were admitted to paediatric general health outpatient clinics from the same period of time without any respiratory problems and previous history of infection.

Diagnosis of anaemia was based on $\mathrm{Hb}$ levels below 2 SD of the age-matched levels. ${ }^{14}$ The CBC was performed by flow cytometry using the $\mathrm{BC}$ 6800 Mindray Auto Hematology Analyser (Shenzhen Mindray Bio-Medical). Statistical analysis of the study was performed using IBM SPSS Statistics for Windows, Version 22.0. The normality analysis of the data was done using the Shapiro-Wilk test. Descriptive values were expressed as numbers (n), percentages (\%). Variables that did and did not conform to normal distribution were indicated as mean $\pm \mathrm{SD}$, and as median (Q1-Q3), respectively. For comparisons of 
groups with and without normal distribution, Student's t-test and Mann-Whitney $U$ test were used respectively. Comparison of categorical variables was done using Pearson chi-square test. Kruskal-Wallis Test was used to compare more than two groups that did not fit the normal distribution. The results were considered significant for $\mathrm{p}<0.05$ within $95 \%$ confidence interval.

ROC curve analysis was performed to determine the cut-off value for $\mathrm{Hb}$, which can predict the development of severe bronchiolitis in patients with AB. Risk analysis was performed with logistic regression test according to the $\mathrm{Hb}$ cut-off value and other etiological factors. Values with a $p$ value of $<0.05$ were considered statistically significant.

\section{RESULTS}

The median age of the patients was five months (4 -8 months) and 58 patients (57\%) were males. No significant differences were found between the patients and healthy groups in terms of age or gender. Median $\mathrm{Hb}$ and $\mathrm{MCHC}$ levels were significantly lower in infants with $\mathrm{AB}$ than controls $\{10.1 \mathrm{gm} / \mathrm{dL}(9.6-10.6 \mathrm{gm} / \mathrm{dL})$ vs. $11.2(10.6-$ $12.1 \mathrm{gm} / \mathrm{dL}) ; \mathrm{p}<0.001\}$ and $\{33.6 \mathrm{gm} / \mathrm{dL}(32.5-$ $34.1 \mathrm{gm} / \mathrm{dL})$ vs. $34 \mathrm{gm} / \mathrm{dL}(33.1-34.5 \mathrm{gm} / \mathrm{dL}) \mathrm{p}=$ 0.012 , respectively\}. Conversely, median RDW was higher in patient group than healthy group $\{14.4 \%(13.5-15.6 \%)$ vs. $14.1 \%(13.1-15 \%) ; p=$ 0.032 , respectively $\}$. The comparison of demographic data between the patient and healthy groups is shown in Table 1.

When the patients were evaluated according to the severity of $A B, 20(19.8 \%)$ patients were in the mild, $56(55.4 \%)$ in the moderate and $25(24.8 \%)$ in the severe group. When patient subgroups were compared according to $\mathrm{Hb}$ levels, the patients with severe $\mathrm{AB}$ had lower $\mathrm{Hb}$ levels than the patients with mild $\mathrm{AB}\{9.33 \mathrm{gm} / \mathrm{dL}(9-9.9 \mathrm{gm} / \mathrm{dL})$ vs. 10.3 $\mathrm{gm} / \mathrm{dL}(10.1-10.8 \mathrm{gm} / \mathrm{dL}) ; \mathrm{p}<0.001$, respectively $\}$. Also, when compared according to RDW values, the median value of RDW was $13.8 \%$ (13.05 $14.4 \%)$ in the mild, $14.7 \%(13.5-15.9 \%)$ in the moderate and $15.0 \%(14-15.7 \%)$ in the severe group. The median RDW was statistically significantly higher in patients with severe than in patients with mild AB $(\mathrm{p}<0.033)$. However, there was no significant difference in MCHC levels between subgroups (Table 2).

We performed ROC curve analysis to determine the $\mathrm{Hb}$ cut-off value in the development of severe $\mathrm{AB}$ in patients with $\mathrm{AB}$. Accordingly, we predicted that patients with $\mathrm{AB}$ with $\mathrm{Hb}$ value $\leq 9.95 \mathrm{gm} / \mathrm{dL}$ may have severe bronchiolitis with $73.7 \%$ sensitivity and $83.3 \%$ specificity (Table 3 ). When the risk factors that may cause the development of severe $\mathrm{AB}$ were evaluated by logistic regression analysis, we found that the risk of suffering from severe $A B$ in patients with $A B$ with a $\mathrm{Hb}$ value of $\leq 10 \mathrm{gm} / \mathrm{dL}$ increased 10 times. Gender and age do not pose a risk. When we look at the correlation between $\mathrm{Hb}$ level and severity of $\mathrm{AB}$, we found that there was a significant negative correlation between ( $\mathrm{r}$ :- 0.423 , $p<0.001) \mathrm{Hb}$ level and severity of AB. There was no significant correlation between age and severity of $\mathrm{AB}(\mathrm{r}$ :- $0.032, \mathrm{P}=0.748)$ (Table 4).

Table 1. Comparison of demographic characteristics and laboratory parameters between children with acute bronchiolitis and healthy controls

\begin{tabular}{|c|c|c|c|}
\hline Variables & $\begin{array}{l}\text { Patient } \\
\text { group }\end{array}$ & Control group & $\begin{array}{c}p- \\
\text { value }\end{array}$ \\
\hline $\begin{array}{l}\text { Age (median) } \\
(25-75) \text { (months) }\end{array}$ & $5(4-8)$ & $5(4-9)$ & ns \\
\hline Gender, n (\%) & & & \\
\hline Female/ & $43(43)$ & $33(53)$ & ns \\
\hline Male & $58(57)$ & $29(47)$ & \\
\hline $\mathrm{Hb}(\mathrm{gm} / \mathrm{dL})$ & 10.1 & 11.2 & $*<$ \\
\hline Median $(25-75)$ & $(9.6-10.6)$ & $(10.6-12.1)$ & 0.001 \\
\hline RDW\% & 14.4 & 14.1 & 0.032 \\
\hline Median (25 - 75) & $(13.5-15.6)$ & $(13.1-15)$ & \\
\hline $\mathrm{MCV}(\mathrm{fL})$ & 80.6 & 84.7 & ns \\
\hline Median $(25-75)$ & $(75.9-88)$ & $(75.2-90.4)$ & \\
\hline $\mathrm{MCH}(\mathrm{pg})$ & 28.1 & 27.5 & ns \\
\hline Median $(25-75)$ & $\begin{array}{r}(25.2- \\
30.4)\end{array}$ & $(24.9-30.5)$ & \\
\hline MCHC (gm/dL) & 33.6 & 34 & 0.012 \\
\hline Median $(25-75)$ & $(32.5-34.1)$ & $(33.1-34.5)$ & \\
\hline \multicolumn{4}{|c|}{$\begin{array}{l}\text { Hb: Hemoglobin, MCV: Mean corpuscular volume, RDW: } \\
\text { Red cell distribution volume, MPV: Mean platelet volume; } \\
\text { PDW: Platelet distribution width, } \mathrm{LL}: \text { Femtolitre, } m g \text { : } \\
\text { miligram, dL: decilitre; pg, picogram.Values are expressed as } \\
\text { median }(25-75) .{ }^{*} p<0.005 \text {. }\end{array}$} \\
\hline
\end{tabular}


Table 2. The differences in the measurements of hemoglobin levels according to bronchiolitis severity score

\begin{tabular}{|lrrrr|} 
Variable & \multicolumn{1}{c}{$\begin{array}{c}\text { Severe } \\
\text { Median }(\mathbf{Q} \text { - Q3) }\end{array}$} & $\begin{array}{c}\text { Moderate } \\
\text { Median }(\mathbf{Q} \text { - Q3) }\end{array}$ & \multicolumn{1}{c|}{$\begin{array}{c}\text { Mild } \\
\text { Median }(\mathbf{Q} \text { - Q3) }\end{array}$} & \multicolumn{1}{c}{ p value } \\
\hline $\mathrm{Hb}(\mathrm{gm} / \mathrm{dL})$ & $9.33(9-9.9) \mathrm{a}$ & $10.1(9.8-10.6) \mathrm{a}$ & $10.3(10.1-10.8) \mathrm{b}$ & $<0.001^{*}$ \\
$\mathrm{MCHC}(\mathrm{gm} / \mathrm{dL})$ & $33.4(32.5-34.0)$ & $33.6(32.4-34.1)$ & $33.5(32.9-34.0)$ & 0.943 \\
$\mathrm{RDW}(\%)$ & $15.0(14-15.7) \mathrm{b}$ & $14.7(13.5-15.9) \mathrm{ab}$ & $13.8(13.05-14.4) \mathrm{a}$ & 0.033
\end{tabular}

Hb: Hemoglobin, MCHC: mean cell hemoglobin concentration, RDW: red cell distribution width. Values are expressed as median (25 - 75). ${ }^{*} p<0.05$. g: Gram, dL: deciliter

\section{DISCUSSION}

In this study we found that patients with $\mathrm{Hb}$ levels less than $10 \mathrm{gm} / \mathrm{dL}$ had 10 times higher risk of severe AB than patients with normal $\mathrm{Hb}$ levels. The patients with lower $\mathrm{Hb}$ levels also had longer hospital stay. Also, there was a significant negative correlation between severity of $\mathrm{AB}$ and $\mathrm{Hb}$ level ( $\mathrm{r}:-0.423, \mathrm{p}<0.001)$. So, it was thought that $\mathrm{Hb}$ level could be an independent risk factor for clinical severity in infants with $\mathrm{AB}$.

Anaemia is defined by the decrease in haemoglobin level below 2 SD compared to the age-adjusted average values. ${ }^{15}$ Anaemia can affect 60 to $70 \%$ of children with respiratory tract infection in countries where the risk of IDA is particularly high. ${ }^{7,8}$

Many studies have observed an association between IDA and the risk of developing LRTI in paediatric patients. We found a significant negative correlation between $\mathrm{Hb}$ level and severity of $\mathrm{AB}$. The risk of severe $\mathrm{AB}$ increased 10 times in patients with $\mathrm{AB}$ with a $\mathrm{Hb}$ value of $\leq 10 \mathrm{gm} / \mathrm{dL}$. Furthermore, the patients who had $\mathrm{Hb}$ value under $9.95 \mathrm{gm} / \mathrm{dL}$ had a risk of more severe bronchiolitis with $73.7 \%$ sensitivity and $83.3 \%$ specificity than

Table 3. Determination of the haemoglobin cut-off values for the development of severe bronchiolitis

\begin{tabular}{|c|c|c|c|c|c|}
\hline & $\begin{array}{c}\text { Cut- } \\
\text { off } \\
\text { value }\end{array}$ & $\begin{array}{c}\text { Sensiti } \\
\text { vity }\end{array}$ & $\begin{array}{l}\text { Specifi } \\
\text { city }\end{array}$ & $\begin{array}{c}\text { Asympto } \\
\text { tic } 95 \% \\
\text { Confiden } \\
\text { ce } \\
\text { Interval }\end{array}$ & $\underset{\text { value }}{\mathbf{p}}$ \\
\hline $\begin{array}{l}\mathrm{Hb} \\
(\mathrm{gm} / \mathrm{dL})\end{array}$ & $\leq 9.95$ & 0.737 & 0.833 & $\begin{array}{r}0.676- \\
0.904\end{array}$ & $\begin{array}{r}< \\
0.001\end{array}$ \\
\hline
\end{tabular}

other patients. Mourad et al. claimed that children with $\mathrm{Hb}$ level below $11 \mathrm{gm} / \mathrm{dL}$ were two times more susceptible to LRTI compared to the control group. ${ }^{9}$ Dhivyanarayani $\mathrm{M}$ et al. showed that $\mathrm{AB}$ is the most common cause of LRTI in children aged two months to five years. Contrary to our study, they showed that the severity of illness assessed by the number of hospitalisation days was similar in anaemic and non-anaemic groups. ${ }^{16}$ In another publication, Hussain et al. showed in a study of 220 children from one month to five years of age that anaemic patients were 4.6 times more likely to develop LRTI. ${ }^{7}$ Similarly, Malla et al. found that among 150 children from one month to five years, anaemic children were 3.2 times more susceptible to LRTI compared to the control group and IDA was predominating. ${ }^{17}$

Iron is an essential element that affects capacity of the immune system to achieve sufficient immunity. ${ }^{18}$ Several investigators showed decreased levels of several cytokines in IDA. ${ }^{19}$ Hassan et al. showed that serum interleukin-6 (IL-6) levels were significantly lower in IDA children than controls. Furthermore, they speculated that there was a significantly positive correlation between serum

Table 4. Analysis of risk factors for the development of severe bronchiolitis

\begin{tabular}{|lrccr|} 
& \multicolumn{1}{c}{ OR } & $\mathbf{9 5 \%}$ Cl & p value & Risk \\
\hline $\begin{array}{l}\mathrm{Hb} \leq 10 \\
\text { gm/dL }\end{array}$ & 10.096 & $3.135-3.251$ & $<0.001$ & Yes \\
Gender & 0.746 & $0.301-1.851$ & 0.528 & No \\
Age & 1 & $0.996-1.003$ & 0.927 & No \\
\hline
\end{tabular}

Statistics: Logistic Regression analysis: OR, oddsratio; CI, confidence interval. ${ }^{*} p<0.05$.

Hb: Hemoglobin, g: Gram, dL: deciliter 
iron and IL-6 levels. ${ }^{20}$ Similarly, Ekiz et al. and Feng-Xue et al. showed that serum IL-6 levels in the patient group with IDA were significantly lower than the control group..$^{21,22}$

The effect of iron deficiency on immune system function was evaluated firstly by Joynson et al. ${ }^{23}$ They reported that immune defects in iron deficiency include decreased cell-mediated immunity, mitogen responsiveness and naturalkiller cell activity. T-cell dysfunction may be the result of low cytokine activity. Cytokines derived from $\mathrm{T}$ cells and monocytes regulate cellular iron homeostasis by affecting the expression of proteins involved in the uptake and storage of the metal. Pro-inflammatory cytokines such as IL-1, IL-6 or tumour necrosis factor-alfa (TNF-a) derived from monocytes and $\mathrm{T}$ cells directly induce the duplication and translation of the ferritin. Decreased cell-mediated immune mitogen sensitivity and a decrease in natural killer activity may also be due to lower IL-6 levels. Moreover, the reduction in $\mathrm{Hb}$, may adversely affect the functions of the normal alveolar macrophages because alveolar macrophages derive iron primarily from the catabolised erythrocytes and plasma pool. So, their function may be blocked in an iron deficient state. $^{24}$

Haemoglobin facilitates oxygen $\left(\mathrm{O}_{2}\right)$ and carbon dioxide $\left(\mathrm{CO}_{2}\right)$ transport. The aggravating effect of anaemia in $\mathrm{AB}$ can be based on the fact that fewer $\mathrm{Hb}$ molecules are not enough to transfer the excess $\mathrm{CO}_{2}$ to the arterialised blood from the bypassed areas. In the presence of anaemia, this excess $\mathrm{CO}_{2}$ will mainly result in the form of dissolved $\mathrm{CO}_{2}$, leading to an increase in clinical scores of $\mathrm{AB}$. Also, the principal physiologic function of $\mathrm{Hb}$ is to carry and deliver $\mathrm{O}_{2}$ to the tissues from the lungs and acts as a buffer for nitric oxide..$^{25}$

The common reason for anaemia is especially nutritional IDA and most often infants aged between three to 23 months were affected. ${ }^{26}$ In our study, we found that MCV and MCHC values were significantly lower as in IDA in children less than two years old. The etiology of anaemia could not be determined precisely due to the absence of anaemia markers. Serum ferritin level was not calculated due to unavailability of this test and ferritin level is not reliable in cases with infection as it increases probably as acute phase protein. ${ }^{27-30}$

This study suggested that coexistence of anaemia may worsen the clinical expression of $\mathrm{AB}$ in the infants. Hence, diagnosis and treatment of IDA could lead to reduction in incidence and severity of $\mathrm{AB}$ in children below two years of age. However, our findings need to be corroborated with further larger prospective studies in the future.

\section{CONCLUSIONS}

$\mathrm{Hb}$ level could be an independent risk factor for the clinical severity of AB. Early and accurate diagnosis and treatment of IDA in infants may prevent incidence and severity of $\mathrm{AB}$.

\section{REFERENCES}

1. Miron D, Srugo I, Kra-Oz Z, Keness Y, Wolf D, Amirav I, et al. Sole pathogen in acute bronchiolitis: is there a role for other organisms apart from respiratory syncytial virus? Pediatr Infect Dis J. 2010;29(1):7-10. DOI: 10.1097/INF. $0 \mathrm{~b} 013 \mathrm{e} 3181 \mathrm{c} 2 \mathrm{a} 212$

2. Ralston SL, Lieberthal AS, Meissner HC, Alverson BK, Baley JE, Gadomski AM, et al. Clinical practice guideline: the diagnosis, management, and prevention of bronchiolitis. Pediatrics. 2014;134(5):1474-502. DOI: https://doi.org/10.1542/peds.2014-2742

3. Zorc JJ, Hall CB. Bronchiolitis: recent evidence on diagnosis and management. Pediatrics. 2010;125(2):342-9. DOI: https://doi.org/10.1542/peds.2009-2092

4. Shay DK, Holman RC, Newman RD, Liu LL, Stout JW, Anderson LJ. Bronchiolitis-associated hospitalizations among US children, 1980-1996. Jama. 1999;282(15):1440-6. DOI:10.1001/jama.282.15.1440 
5. Leader S, Yang H, DeVincenzo J, Jacobson P, Marcin JP, Murray DL. Time and out-of-pocket costs associated with respiratory syncytial virus hospitalization of infants. Value in Health. 2003;6(2):100-6. DOI: https://doi.org/ 10.1046/j.1524-4733.2003.00220.x

6. Chandra RK. Nutrition and the immune system from birth to old age. Eur J Clin Nutr. 2002;56(3):S73-S76. DOI: $10.1038=$ sj.ejen. 1601492

7. Hussain SQ, Asheraf M, MA, Wani JG, Ahmed J. Low hemoglobin level a risk factor for acute lower respiratory tract infections (ALRTI) in children. J Clin Diagn Res.2014;8(4):1-3. DOI: 10.7860/JCDR/2014/8387.4268

8. Ramakrishnan K, Harish P. Hemoglobin level as a risk factor for lower respiratory tract infections. Indian J Pediatr. 2006;73(10):881-3. DOI: 10.1007/BF02859279

9. Mourad S, Rajab M, Alameddine A, Fares M, Ziade F, Abou Merhi B. Hemoglobin level as a risk factor for lower respiratory tract infections in Lebanese children. N Am J Med Sci. 2010;2(10):461-6. DOI: 10.4297/najms. 2010.2461

10. Piedra PA, Stark AR. Bronchiolitis in infants and children: Treatment; outcome; and prevention. UpToDate. 2013.

11. Court SDM. The definition of acute respiratory illnesses in children. Postgrad Med J. 1973;49:771-6. DOI: 10.1136/ pgmj. 49.577 .771

12. Clarke SKR, Gardner PS, Poole PM, Simpson H, Tobin JHV. Respiratory syncytial virus infection: admissions to hospital in industrial, urban and rural areas. Report to the Medical Research Council subcommittee on respiratory syncytial virus vaccines. Br Med J. 1978;ii:796-8. DOI: 10.1136/bmj.2.6140.796

13. Wang EE, Milner RA, Navas L, Maj H. Observer agreement for respiratory signs and oximetry in infants hospitalized with lower respiratory infections. Am Rev Respir Dis. 1992;145(1): DOI: 106-109.https://doi.org/ 10.1164/ajrccm/145.1.106

14. Hassan TH, Badr MA, Karam NA, Zkaria M, Saadany HF, Rahman DMA et al. Impact of iron deficiency anemia on the function of the immune system in children. Medicine. 2016;95:47. DOI: 10.1097/MD.0000000000005395

15. Swaanenburg J, Rutten W, Holdrinet A, Van Strik R. The determination of reference values for hematologic parameters using results obtained from patient populations. Am J Clin Pathol. 1987;88(2):182-91. DOI: https:// doi.org/10.1093/ajcp/88.2.182

16. Dhivyanarayani M. Study of clinical profile of acute lower respiratory tract infection in children aged 2 months to 5 years. Int J Contemp Pediatr. 2018;5(4):1322. DOI: http://dx.doi.org/10.18203/2349-3291.ijcp20182432

17. Malla T, Pathak OK, Malla KK. Is low hemoglobin level a risk factor for acute lower respiratory tract infections? J Nepal Paediatr Soc. 2010;30(1):1-7. DOI: https://doi.org/10.3126/jnps.v30i1.2453

18. Mascotti DP, Rup D, Thach RE. Regulation of iron metabolism: translational effects mediated by iron, heme, and cytokines. Annu Rev Nutr. 1995;15(1):239-61. DOI: https://doi.org/10.1146/annurev.nu.15.070195.001323

19. Kochanowski BA, Sherman AR. Phagocytosis and lysozyme activity in granulocytes from iron-deficient rat dams and pups. Nutrition Research. 1984;4(3):511-20. DOI: https://doi.org/10.1016/S0271-5317(84)80111-6

20. Culebras E, Betriu C, Vázquez-Cid E, López-Varela E, Rueda S, Picazo JJ. Detection and genotyping of human respiratory viruses in clinical specimens from children with acute respiratory tract infections. Rev Esp Quimioter. 2013;26(1):47-50.

21. Ekiz C, Agaoglu L, Karakas Z, Gurel N, Yalcin I. The effect of iron deficiency anemia on the function of the immune system. Hematol J. 2005;5(7):579-83. DOI: 10.1038/sj.thj.6200574.

22. Feng X, Yang X, Shen J. Influence of iron deficiency on serum IgG subclass and pneumococcal polysaccharides specific IgG subclass antibodies. Chin Med J. 1994;107(11):813. PMID: 7867386

23. Joynson D, Walker DM, Jacobs A, Dolby AE. Defect of cell-mediated immunity in patients with iron-deficiency anaemia. The Lancet. 1972;300(7786):1058-9. DOI: https://doi.org/10.1016/S0140-6736(72)92340-9

24. Mateos F, Brock JH, Pérez-Arellano JL. Iron metabolism in the lower respiratory tract. Thorax. 1998;53(7): 594-600. DOI: http://dx.doi.org/10.1136/thx.53.7.594

25. Ganong WF. Review of medical physiology. Mcgraw-hill; 1995.

26. Kotecha PV. Nutritional anemia in young children with focus on Asia and India. Indian J community Med: official publication of Indian Association of Preventive \& Social Medicine. 2011;36(1):8. DOI: 10.4103/0970-0218.80786 
27. Bhaskaram P, Nair KM, Balakrishna N, Ravinder P, Sesikeran B. Serum transferrin receptor in children with respiratory infections. Eur J Clin Nutr. 2003;57(1):75-80. DOI: 10.1038=sj.ejcn.1601496

28. Tansu S, Tulin K, Betul T. The effects of acute infection on hematological parameters. Pediatr Hematol Oncol. 2004;21:511-8. DOI: 10.1080/08880010490477301

29. Rahman MA, Mannan M, Rahman MH. Influence of infection on iron profile in severely malnourished children. Indian J Pediatr. 2009;76(9):907. DOI: https://imsear.searo.who.int/handle/123456789/142367

30. Ryan AS. Iron-deficiency anemia in infant development: Implications for growth, cognitive development, resistance to infection, and iron supplementation. Am J Phys Anthropol. 1997;104(S25):25-62. DOI: https://doi.org/ 10.1002/(SICI)1096-8644(1997)25 